\title{
PENGEMBANGAN PARIWISATA ALAM \\ DI KECAMATAN PONCOKUSUMO MENGGUNAKAN SISTEM INFORMASI GEOGRAFIS BERBASIS WEB
}

\author{
${ }^{1)}$ Adinda Ristia Saraswati; ${ }^{2)}$ Ahmad Maulana Malik Jamil \\ ${ }^{1)}{ }^{2)}$ Universitas Kanjuruhan Malang \\ Email: ${ }^{1)}$ adindaristiasaraswati@gmail.com; ${ }^{2)}$ maulana3188@gmail.com
}

\begin{abstract}
Abstrak
Kecamatan Poncokusumo merupakan daerah agrowisata di Kabupaten Malang, Tujuan penelitian ini membuat pengembangan pariwisata dengan menggunakan sistem informasi geografis berbasis web sehingga informasi tersebut dapat diakses dengan mudah oleh masysrakat. Metode yang digunakan dalam penelitian ini adalah kuesioner, wawancara dan dokumentasi. Subyek dalam penelitian ini adalah wisatawan yang datang ke obyek wisata, pengelola obyek wisata alam yang berada di Kecamatan Poncokusumo, tokoh masyarakat di sekitar obyek wisata alam dan Dinas Pariwisata Kabupaten Malang. Penelitian ini merupakan penelitian kualitatif menggunakan analisis SWOT dalam pengembangan pariwisata alam di Kecamatan Poncokusumo. Berdasarkan hasil penelitian, banyak sekali potensi alam yang berada di Kecamatan Poncokusumo antara lain coban bidadari, coban pelangi, ledok ombo, gunungsari sunset, river tubing ledok ombo dan juga river tubing sedaer.
\end{abstract}

Kata Kunci: Pengembangan pariwisata alam, Sistem Informasi Geografis, berbasis Web

\section{PENDAHULUAN}

Pariwisata alam yang berada di Kecamatan Poncokusmo tersebar diberbagai titik di desa-desa Kecamatan Poncokusumo, yaitu di Desa Gubuklakah, Desa Ngadas, Desa Poncokusumo, Desa Wringinanom. Karena 4 desa tersebut yang menjadi desa penyanggah menuju Taman Nasioanal Bromo Tengger Semeru menjadikan desa-desa tersebut menjadi tempat singgah. Mengembangkan potensi yang ada di desa-desa tersebut menjadi destinasi wisata yang wajib dikunjungi sebelum menuju Bromo dan Semeru.

Kurang beragamnya promosi pariwisata di Kecamatan Poncokusumo juga menjadi kendala dan mendapatkan akses informasi akan memberikan kemudahan untuk masyarakat dalam berbagai hal terutama dalam bidang pariwisata. Kurangnya akses online untuk promosi pariwisata dan diperlukannya pengembangan dan promosi pariwisata yang sebenarnya yang akan mempermudah masyarakat dan wisatawan untuk mendapatkan informasi pariwisata akan dangat mempermudah dalam mempromosikan pariwisata di Kecamatan Poncokusumo.

Salah satu kunci dari susksesnya suatu industri pariwisata adalah promosi agar pariwisatanya lebih berkembang, maka perlu adanya informasi yang mendukung mengenai suatu kawasan wisata. Dengan adanya promosi pariwisata dan kemudahan dalam pencarian informasi pariwisata suatu daerah merupakan faktor yang dominan dalam menentukan jumlah wisatawan yang berkunjung. 
Berdasarkan latar belakang masalah yang telah dijelaskan di atas maka rumusan masalah dalam penelitian ini adalah bagaimana membuat pengembangan pariwisata dengan menggunakan sistem informasi geografis berbasis web sehingga informasi pariwisata alam tersebut dapat diakses dengan mudah oleh masyarakat dan wisatawan.

Menurut Marpaung (2002) perkembangan pariwisataan bertujuan memberikan keuntungan baik bagi wisatawan maupun warga setempat. Pariwisata dapat memberikan kehidupan yang standar kepada warga setempat melalui keuntungan ekonomi yang didapat dari tempat tujuan wisata.

Menurut beberapa pakar seperti Cooper, Fletcherm Gilbertm Stepherd and Wanhill (1998) dalam Mustika, AJ, Ika, M, (2016:18) menjelaskan bahwa daerah tujuan wisata memiliki paling tidak harus mencakup komponenkomponen utama sebagai berikut: obyek atau daya tarik, aksesibilitas, amenitas, fasilitas pendukung dan kelembagaan

Pengertian lain tentang pemetaan yaitu sebuah tahapan yang harus dilakukan dalam pembuatan peta. Langkah awal yang dilakukan dalam pembuatan data, dilanjutkan dengan pengolahan data, dan penyajian dalam bentuk peta (Juhadi dan Liesnoor, 2001).

Pendit (2002:33) menjelaskan tentang kepariwisataan sebagai berikut: Kepariwisataan juga dapat memberikan dorongan langsung terhadap kemajuankemajuan pembangunan atau perbaikan pelabuhan-pelabuhan (laut atau udara), jalan-jalan raya, pengangkutan setempat, program-program kebersihan atau kesehatan, proyek sarana budaya dan kelestarian lingkungan, dan sebagainya, yang semuanya dapat memberikan keuntungan dan kesenangan baik bagi wisatawan dalam lingkungan wilayah yang bersangkutan, maupun bagi wisatawan pengunjung dari luar.

Menurut ESRI bahwa: Sistem Informasi Geografis adalah kumpulan yang terorganisir dari perangkat keras komputer, perangkat lunak, data geografi dan personil yang dirancang secara efisien untuk memperoleh, menyimpan, meng-update, memanipulasi, menganalisis dan menampilkan semua bentuk informasi yang bereferensi geografis (dalam Eddy Prahasta, 2005).

Website atau situs dapat diartikan sebagai kumpulan halaman-halaman yang digunakan untuk menampilkan informasi teks, gambar diam atau gerak, animasi, suara, dan atau gabungan dari semuanya itu baik yang bersifat statis maupun dinamis yang membentuk satu rangkaian bangunan yang saling terkait dimana masing-masing dihubungkan dengan jaringan-jaringan halaman (hyperlink).

Geografi pariwisata selalu melihat dampak terhadap lingkungan alam, social, ekonomi, dan budaya penduduk. Konsep-konsep geografi, seperti: lokasi, jarak, keterjangkauan, interaksi, keterkaitan, dan nilai guna selalu menjadi dasar dalam menjelaskan fenomena pariwisata. Menurut Pearce (dalam Mustika, AJ, Ika, M, 2016) Terdapat enam wilayah topik yang menyusun komponen geografi pariwisata yaitu: pola keruangan dari permintaan, pola keruangan dari penawaran, sumberdaya geografi untuk pariwisata, geografi dan aliran 
wisatawan, dampak pariwisata, model keruangan pariwisata.

\section{METODE PENELITIAN}

Berdasarkan masalah dan rumusan masalah, jenis penelitian ini merupakan penelitian deskriptif kualitatif yaitu penelitian tentang data yang dikumpulkan dan dinyatakan dalam bentuk kata-kata dan gambar kata-kata disusun dalam kalimat. Misalnya kalimat hasil dokumentasi observasi, wawancara antara peneliti dan informan. Kehadiran peneliti di lapangan dalam penelitian kualitatif menurut Miles dan Huberman (2008) adalah suatu yang mutlak, karena peneliti bertindak sebagai instrumen penelitian sekaligus pengumpul data.

Penelitian ini dilaksanakan di Kecamatan Poncokusumo dengan tepat penelitian seluruh tempat wisata alam di Kecamatan Poncokusumo. Sumber data yang digunakan merupakan data primer yaitu dalam penelitian ini adalah kuesioner, wawancara dan dokumentasi, sedangkan untuk data sekunder yaitu data dari pemerintah Kecamatan Poncokusumo. Subyek penelitian dalam penelitian ini ialah wisatawan, pengelola, tokoh masyarakat dan dinas pariwisata.

Analisis data menggunakan Analisis SWOT, analisis SWOT merupakan salah satu metode mengembangkan kondisi dan mengevaluasi suatu masalah, poyek atau konsep bisnis yang berdasarkankan faktor internal (dalam) dan faktor eksternal. Pemeriksaan keabsahan data yang di peroleh di lakukan dengan cara antara lain: perpanjangan keikutsertaan, ketekunan pengamatan, triangulasi, pemeriksaan sejawat.

\section{HASIL}

Kecamatan Poncokusumo daerah dari 33 kecamatan di wilayah Kabupaten Malang. Secara astronomis Kecamatan Poncokusumo Malang terletak diantara 112,1330 sampai 122,5455 Bujur Timur dan 7,5890 sampai 8,6813 Lintang Selatan. Mengacu pada data potensi Kecamatan Poncokusumo, letak geografi Kecamatan Poncokusumo adalah dataran. Sebagian lagi berupa Lereng dengan topografi tergolong datar dan perbukitan. Adapun pariwisata alam yang berada di kecamatan Poncokusumo tersebar di 4 desa yaitu: Desa Poncokusumo, Desa Ngadas, Desa Gubukklakah, dan Desa Wringinanom

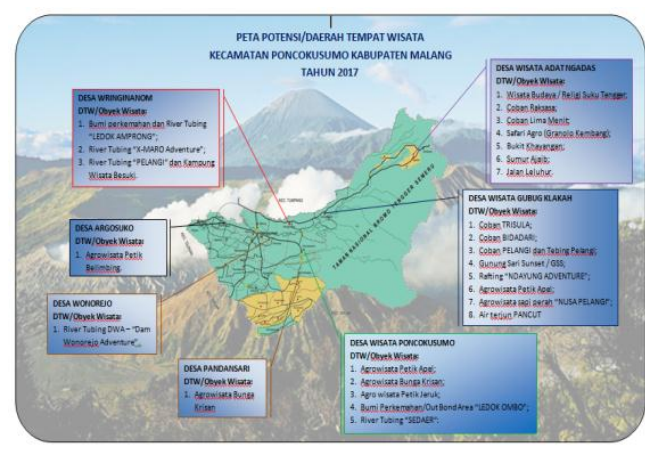

\section{Gambar 1. Sebaran Obyek Wisata di Kecamatan Poncokusumo Sumber: Arsip Kecamatan Poncokusumo}

\section{a. Paparan Data Obyek Wisata Coban Bidadari}

Desa Wisata Gubugklakah memiliki sejumlah potensi obyek dan daya tarik wisata, salah satunya Air Terjun Coban Bidadari. Coban Bidadari terletak di bawah kawasan Taman Nasional Bromo Tengger Semeru. 
Tabel 1. Responden Kuesioner

\begin{tabular}{|c|c|c|c|c|}
\hline No. & Nama & Alamat & Umur & $\begin{array}{c}\text { Jenis } \\
\text { Kelamin }\end{array}$ \\
\hline 1. & $\begin{array}{c}\text { Retno } \\
\text { Wulandari }\end{array}$ & Wajak & 22 th & Perempuan \\
\hline 2. & $\begin{array}{c}\text { Jamila Putri } \\
\text { Adelia }\end{array}$ & Wajak & 14 th & Rerempuan \\
\hline 3. & Hanik & $\begin{array}{l}\text { Kidang } \\
\text { bang } \\
\text { Wajak }\end{array}$ & 35 th & Rerempuan \\
\hline 4. & Sumaixah & Wlajak & 39 th & Rerempuan \\
\hline 5. & $\begin{array}{c}\text { Lathifa } \\
\text { Alghannivya }\end{array}$ & Wajak. & 16 th & Rerempuan \\
\hline
\end{tabular}

Sumber: Penelitian 2018

Kuesioner yng telah disebarkan dan menurut hasil wawancara dengan pengelola, wisatawan mengetahui coban bidadari dari social media dan juga dari teman dengan spot foto yang menarik dan juga air terjun yang indah menjadi salah satu daya tarik, hanya dengan membayar Rp. 10.000,-/orang. Wisatawan sudah dapat sepuasnya menikmati wisata di coban bidadari dengan keamanan yang terjamin serta disediakannya kotak P3T apabila ada kecelakaan, sarana dan prasarana yang lengkap serta banyak homestay yang tersedia di Desa Wisata Gubukklakah beserta penyewaan jeep dan trail dan tak lupa ada rumah makan yang tersedia sebelum menuju ke coban bidadari yaitu warung arema dan Food Court NUSA PELANGI dan untuk SPBU hanya 1 yaitu tersedia di Desa Tulusayu dan ada 1 lagi SPBU yang masih dalam proses tahap pembangunan yang berada di Desa Wringinanom.

\section{b. Paparan Data Obyek Wisata Coban Pelangi}

Air Terjun Coban Pelangi yang terletak di Desa Gubugklakah, Kecamatan Poncokucumo, Kabupaten Malang. Wisata Coban Pelangi terletak di Koordinat GPS: $8^{\circ} 1^{\prime} 32.27^{\prime \prime} \mathrm{S} 112^{\circ} 49^{\prime}$ 1.06", Desa Gubugklakah memiliki sejumlah potensi obyek dan daya tarik wisata, salah satunya Air Terjun Coban Pelangi.

Tabel 2. Responden Kuesioner

\begin{tabular}{ccccc}
\hline NO. & Nama & Alamat & Umur & $\begin{array}{c}\text { Jenis } \\
\text { Kelamin }\end{array}$ \\
\hline 1. & Karunia & Turen & 23 th & Perempuan \\
& Dewi & & & \\
2. & Arikka & Mojokerto & 23 th & Perempuan \\
3. & Nina & J1. Arif & 34 th & Perempuan \\
& Amalia & Margono & & \\
& & $8 / 1670$ & & \\
4. Dhimas & J1. KI & 34 th & Pria \\
& & Ageng & & \\
& & Gribig & & \\
5. & Eiga & Buring & 32 th & Perempuan \\
\hline
\end{tabular}

Sumber: Penelitian 2018

Obyek wisata coban pelangi memang sudah terkenal dan banyak wisatawan yang datang dari wisatawn domestic maupu wisatawan mancanegara. Dengan tiket masuk Rp. 10.000,-/orang untuk wisatawan domestic dan Rp. 15.000 ,-/orang untuk wisatawan mancanegara, dengan membayar tiket

Dengan sarana dan prasarana yang memadai bagi wisatawan serta kemanan dan keselamatan yang terjaga. Untuk rumah makan, homestay, transportrasi dan SPBU sama dengan data di coban bidadari.

\section{c. Paparan Data Obyek Wisata Ledok Ombo}

Obyek wisata alam ledok ombo merupak wisata alam yang berada di Desa Poncokusumo. Keindahan hutan pinus menjadikan ledok ombo semakin diminati wisatawan untuk berwisata dan juga bersantai dari hiruk pikuk keramaian kota. 
Tabel 3. Responden Kuesioner

\begin{tabular}{|c|c|c|c|c|}
\hline No. & Nama & Alamat & Umur & $\begin{array}{c}\text { Jenis } \\
\text { Kelamin }\end{array}$ \\
\hline 1. & $\begin{array}{l}\text { Dendi } \\
\text { Alfiyan }\end{array}$ & Wonosari & 20 th & Pria \\
\hline 2. & Lia & Ngebruk & 19 th & $\begin{array}{c}\text { Perempy } \\
\text { an }\end{array}$ \\
\hline 3. & $\begin{array}{c}\text { Nurma } T \\
\text { Anissa }\end{array}$ & $\begin{array}{l}\text { J1. Sutome } \\
\text { No. } 27\end{array}$ & 21 th & $\begin{array}{c}\text { Perempu } \\
\text { an }\end{array}$ \\
\hline 4. & $\begin{array}{l}\text { Aprilia } \\
\text { Danur } \\
\text { Budiarta }\end{array}$ & $\begin{array}{l}\text { J1. Bunga } \\
\text { Kumis } \\
\text { Kucing } 11 \\
\text { Malang }\end{array}$ & 22 th & Pria \\
\hline 5. & $\begin{array}{l}\text { Fahmixuda } \\
\text { Arrizal }\end{array}$ & $\begin{array}{l}\text { J1. Bunga } \\
\text { Kumis } \\
\text { Kucing } 11 \\
\text { Malang }\end{array}$ & 21 th & Pria \\
\hline
\end{tabular}

Obyek wisata yang satu ini menyuguhkan hutan pinus yang indah dan sudah banyak dikethui wisatawan dan juga masyarakat sekitar. Dengan sarana dan prasana yang edukatif serta penmbahan cafe yairu omah akar dan juga omah pinus juga dapat menjadi daya tarik bagi wisatawan. Dengan tiket masuk Rp.5000.00/orang wisatawan dapat menikmati hutan pinus ini sepuasnya serta kemanan dan keselamatan yang terjamin tersedia juga transportrasi dan homestay di Desa Wisata Poncokusumo serta banyak rumah makan sebelum ke ledok ombo antara lain warung hikmah, warung nasi bu sum, warung makan barokah, warung makan jawa. Dan SPBU sama dengan yang ada di paparan data coban bidadari.

\section{d. Paparan Data Obyek Wisata Gunungsari Sunset}

Diharapkan dengan adanya gunungsaru susnset ini bisa menarik wisatawan yang menuju Taman Nasional Bromo Tengger Semeru dan juga singgah untuk menikmati sunset dan juga bermalam di home stay di gunungsari sunset.
Tabel 4. Responden Kuesioner

\begin{tabular}{ccccc}
\hline No. & Nama & Alamat & Umur & $\begin{array}{c}\text { Jenis } \\
\text { Kelamin }\end{array}$ \\
\hline 1. & $\begin{array}{c}\text { Sherli } \\
\text { Rahmavati }\end{array}$ & Wringinanom & 13 th & Perempuan \\
2. & Fransiska & Leak & 20 th & Perempuan \\
& & Tumpang & & \\
3. & Indahyati & Belung & 25 th & Perempuan \\
4. & Hasan & Belung & 25 th & Pria \\
5. & Amalia & Belung & 10 th & Perempuan \\
& Putri & & & \\
\hline
\end{tabular}

Sumber: Penelitian 2018

Obyek wisata gunungsari sunset merupakan wisata baru di Desa Wisata Gubukklakah, wisatawan mengetahui obyek wisata ini dari teman dan juga dari sosial media. Hanya dengan tiket Rp. 10.000,-orang wisatawan dapat menikmati sarana dan prasarana yang memadai serta keindahan alam yang indah menjadikan potensi homestay bagi wisatawan yang ingin menikmari sunset dan menginap di homestay dengan harga Rp. 200.000,-/kamar untuk wisatawan domestik dan $\mathrm{Rp}$. 250.000,-/kamar untuk wisatawan mancanegara.

\section{e. Paparan Data Obyek Wisata River Tubing Ledok Amprong}

Sudah banyak wisatawan yang mengetahui keseruan river tubing di ledok amprong, bermain air dengan cara yang ekstream dengan menguji adrenali yang terdapat di Desa Wringinanom.

\section{Tabel 5. Responden Kuesioner}

\begin{tabular}{|c|c|c|c|c|}
\hline No. & Nama & Alamat & Umur & $\begin{array}{c}\text { Jenis } \\
\text { Kelamin }\end{array}$ \\
\hline 1. & Alvin & $\begin{array}{l}\text { Sedayy } \\
\text { Turen }\end{array}$ & 20 th & Pria \\
\hline 2. & Haikal & Turen & 20 th & Pria \\
\hline 3. & Mikayla & Turen & 20 th & Perempuan \\
\hline 4. & $\begin{array}{l}\text { Calista } \\
\text { Aulidia }\end{array}$ & $\begin{array}{l}\text { Talok } \\
\text { Turen }\end{array}$ & 18 th & Rerempuan \\
\hline 5. & $\begin{array}{c}\text { Fajar } \\
\text { Kusdiantoro }\end{array}$ & $\begin{array}{l}\text { Sedayn } \\
\text { Turen }\end{array}$ & 18 th & Pria \\
\hline
\end{tabular}

Sumber: Penelitian 2018 
Wisatawan yang datang ke obyek wisata ini ingin tubing dan juga ingi menikmati keindahan alam, dengan sarana dan prasarana yang memadai serta dengan tiket masuk Rp. 5000.00.,/orang sudah dilengkapi asuransi untuk wisatawan yang ingin tubing da nada paket wisata dan bisa booking dulu untuk wisatawan yang ingin tubing. Kondisi jalan yang lumayan sulit juga menjadi uji adrenalin sendiri bagi wisatawan.

\section{f. Paparan Data Obyek Wisata River Tubing Sedaer}

River tubing "Sedaer" berada Desa Drigu Desa Poncokusumo, obyek wisata ini terbilang baru di Kecamatan Poncokusumo. Tubing merupakan suatu kegiatan yang membutuhkan kemampuan fisik dan mental yang merupakan tantangan alam, selama tubing wisatawan juga dapat menikmati pemandangan serta suasana alam yang masih asri.

Tabel 6. Responden Kuesioner

\begin{tabular}{ccccc}
\hline N0. & Dama & Alamat & Umur & $\begin{array}{c}\text { Jenis } \\
\text { Kelamin }\end{array}$ \\
\hline 1. & Siswante & Wenomulye & 23 & Laki-laki \\
2. & Wawvan S & Tajinan & 23 & Laki-laki \\
3. & Yudi & Wates & 18 & Laki-laki \\
4. & sandra & pajaran & 20 & Laki-laki \\
5. & - & - & - & - \\
\hline
\end{tabular}

Sumber: Penelitian 2018

Paket tubing yang ditawarkan oleh pengelola salah satunya yaitu $\mathrm{Rp}$. 125.000.00,-/max 5 orang dan jarak tempuh tubing untuk memula $2 \mathrm{KM}$ ditempuh kurang lebih 2 jam. Bermain air 2 jam cukup seru ditambah lagi suasana pedesaan kanan dan kirinya terdapat kebun apel. Wisatawan diajak melewati 17 (tujuh belas) jeram dan 2 (dua) jeram andalan sungai Amprong: Jeram Welcome dan Jeram Sairin dengan ketinggian 2 hingga 3 meter. Sarana dan prasarana di river tubing sedaer cukup lengkap dan ada juga souvenir.

\section{PEMBAHASAN}

\section{Strategi Pengembangan Obyek Wisata Coban Bidadari}

Coban bidadari ini berada dibawah tebing, jadi untuk wisatawan harus melintasi jalan menurun yang sangat menguji adrenalin. Suasana di wilayah sekitar air terjun ini masih begitu asri dengan pohon hijau yang tumbuh dengan subur dan hijau mengelilinginya.

Kekuatan, kelemahan, peluang serta ancaman diperoleh berdasarkan hasil observasi, wawancara kepada pengelola dan kuesioner untuk wisatawan sedangkan untuk skoring merupakan analisi SWOT kuantitatif. Peneliti mengambil skor 1-5 untuk masingmasing analisi SWOT.

\section{Tabel 7. Metode Skoring SWOT}

\begin{tabular}{|c|c|c|c|c|}
\hline No & $\mathrm{S}$ & Skar & Bobot. & Total \\
\hline 1 & $\begin{array}{l}\text { Panorama } \\
\text { alam yang asri }\end{array}$ & 4 & $4 / 5=0.8$ & 3.2 \\
\hline 2 & $\begin{array}{l}\text { Pohon-pohon } \\
\text { pinus yang } \\
\text { rindang }\end{array}$ & 2 & $2 / 5=0.4$ & 0.8 \\
\hline 3 & $\begin{array}{l}\text { Udara yang } \\
\text { sejuk }\end{array}$ & 4 & $4 / 5=0.8$ & 3.2 \\
\hline 4 & $\begin{array}{l}\text { Air terjun } \\
\text { yang } \\
\text { mempesona }\end{array}$ & 4 & $4 / 5=0.8$ & 3.2 \\
\hline 5 & $\begin{array}{l}\text { Spot-spot fote } \\
\text { yang keren }\end{array}$ & 3 & $3 / 5=0.6$ & 1.8 \\
\hline & $\begin{array}{l}\text { Total } \\
\text { Keluatan }\end{array}$ & & & 12.2 \\
\hline No. & W & Skor & Bobot. & Total \\
\hline 1. & $\begin{array}{l}\text { Sumber daya } \\
\text { manusia } \\
\text { kurang }\end{array}$ & 3 & $3 / 5=0.6$ & 1.8 \\
\hline 2. & Kurang dana & 2 & $2 / 5=0.4$ & 0.8 \\
\hline 3. & $\begin{array}{l}\text { Rarkiran } \\
\text { masih tanah }\end{array}$ & 4 & $4 / 5=0.8$ & 3.2 \\
\hline 4. & $\begin{array}{l}\text { Jalan yang } \\
\text { rusal }\end{array}$ & 2 & $2 / 5=0.4$ & 0.8 \\
\hline 5. & $\begin{array}{l}\text { Air yang } \\
\text { masih sulit }\end{array}$ & 1 & $1 / 5=0.2$ & 0.2 \\
\hline & $\begin{array}{l}\text { Total } \\
\text { Kelemahan }\end{array}$ & & & 6.8 \\
\hline
\end{tabular}




\begin{tabular}{|l|l|r|l|l|}
\hline No & \multicolumn{1}{|c|}{ O } & Skor & Bobot & Total \\
\hline 1 & $\begin{array}{l}\text { Uliata colan bidadari } \\
\text { yang lebih asri }\end{array}$ & 4 & $4 / 5=0.8$ & 3.2 \\
\hline 2 & Homestay eksekutif & 3 & $3 / 5=0.6$ & 1.8 \\
\hline 3 & $\begin{array}{l}\text { Produksi souvenir } \\
\text { coban bidadari }\end{array}$ & 4 & $4 / 5=0.8$ & 3.2 \\
\hline 4 & Wlisata Xg lebih unggul & 4 & $4 / 5=0.8$ & 3.2 \\
\hline 5. & $\begin{array}{l}\text { Gardu pandang dengan } \\
\text { beground perbulkitan }\end{array}$ & 5 & $5 / 5=1$ & 5 \\
\hline & \multicolumn{1}{|c|}{ Total Peluang } & & & 16.4 \\
\hline
\end{tabular}

\begin{tabular}{|c|c|c|c|c|}
\hline No. & $\mathrm{T}$ & Skgor & Bobot. & Total \\
\hline 1. & $\begin{array}{l}\text { Kurangnyas } \\
\text { dulkungan } \\
\text { pemerintah } \\
\text { dinas pariwisata }\end{array}$ & 3 & $3 / 5=0.6$ & 1.8 \\
\hline 2 . & $\begin{array}{l}\text { Kalah bersaing } \\
\text { dengan wisata yang } \\
\text { lain }\end{array}$ & 4 & $4 / 5=0.8$ & 3.2 \\
\hline 3. & $\begin{array}{l}\text { Kerusalcan } \\
\text { linglaungan }\end{array}$ & 4 & $4 / 5=0.8$ & 3.2 \\
\hline 4. & $\begin{array}{l}\text { Bencana } \\
\text { longsor danah } \\
\text { teriug }\end{array}$ & 4 & $4 / 5=0.8$ & 3.2 \\
\hline \multirow[t]{2}{*}{5.} & $\begin{array}{l}\text { Kesadaran } \\
\text { wisatawam untuk } \\
\text { gbyek wisata }\end{array}$ & 3 & $3 / 5=0.6$ & 1.8 \\
\hline & Total Ancaman & & & 13.2 \\
\hline
\end{tabular}

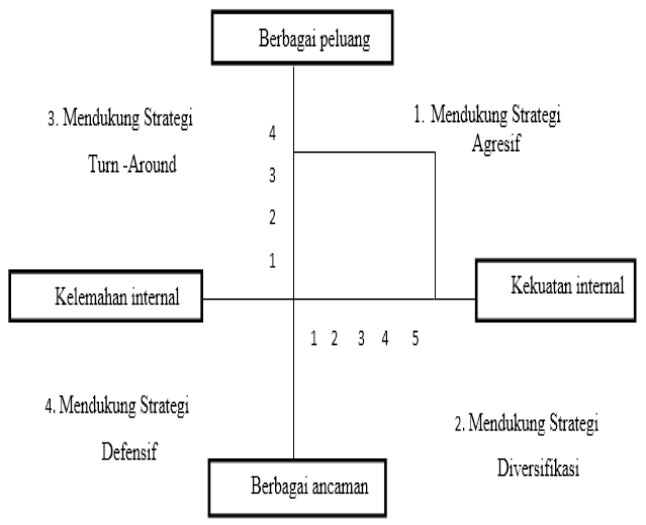

Gambar 2. Matrix Grand Strategy Obyek Wisata Coban Bidadari

\section{Strategi Pengembangan Obyek Wisata Coban Pelangi}

Coban Pelangi berada di kawasan pegunungan perbukitan terjal dengan kemiringan diatas $45 \%$ dan berada di ketinggian 1200-1400 Mdpl. Air terjun Coban Pelangi mengalir dari tebing yang memiliki ketinggian 110 meter. Jika cuaca sedang baik, pengunjung yang beruntung bisa menyaksikan 'Pelangi' yang membiaskan di pucuk-pucuk tebing. Biasanya, Pelangi muncul pada jam 10 pagi sampai jam 2 siang. Fenomena alam itu muncul akibat butiran air terjun yang terbawa angin, serupa buliranbuliran kabut.

\section{Tabel 8. Metode Skoring SWOT Obyek Wisata Coban Pelangi}

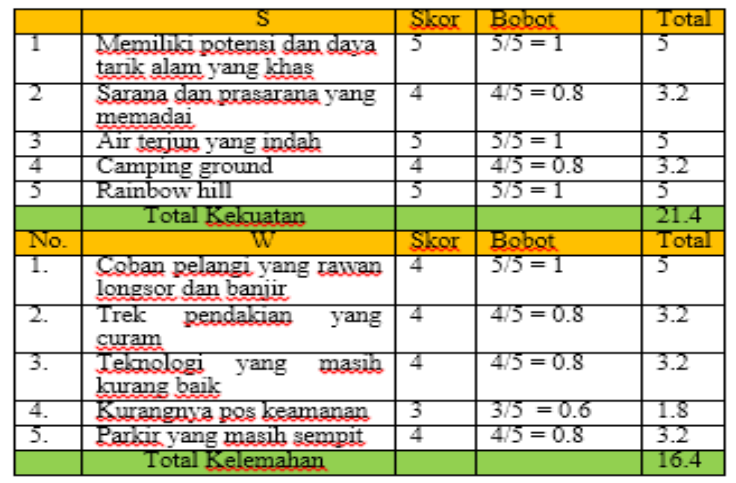

\begin{tabular}{|c|c|c|c|c|}
\hline No & 0 & Sker & Bobot. & Total \\
\hline 1. & Dukungan masyarakat & 5 & $5 / 5=1$ & 5 \\
\hline 2. & Rebuatan souvenir coban pelangi & 4 & $4 / 5=0.8$ & 3.2 \\
\hline 3. & $\begin{array}{l}\text { Minat xisatawan yang cukup. } \\
\text { tinggi }\end{array}$ & 5 & $5 / 5=1$ & 5 \\
\hline 4. & $\begin{array}{l}\text { Gardu pandang serta rumah pohon } \\
\text { yang di dalam rainbow hill }\end{array}$ & 5 & $5 / 5=1$ & 5 \\
\hline \multirow[t]{2}{*}{5.} & $\begin{array}{l}\text { Area outbond untul pendukung } \\
\text { camping ground }\end{array}$ & 5 & $5 / 5=1$ & 5 \\
\hline & Total Peluang & & & 23.2 \\
\hline No. & $\mathrm{T}$ & Sker & Bobot & Total \\
\hline 1. & $\begin{array}{l}\text { Rerilaku yang kurang baiks } \\
\text { penguniung }\end{array}$ & 2 & $2 / 5=0.4$ & 0.8 \\
\hline 2. & Air terjun lain yang lebih menariks & 3 & $3 / 5=0.6$ & 1.8 \\
\hline 3. & Ancaman bencana longsor & 4 & $4 / 5=0.8$ & 3.2 \\
\hline 4. & Renurunan jumlah wisatawan & 5 & $5 / 5=1$ & 5 \\
\hline \multirow[t]{2}{*}{5.} & Kerusakan alam & 4 & $5 / 5=1$ & 5 \\
\hline & Total Ancaman & & & 15,8 \\
\hline
\end{tabular}

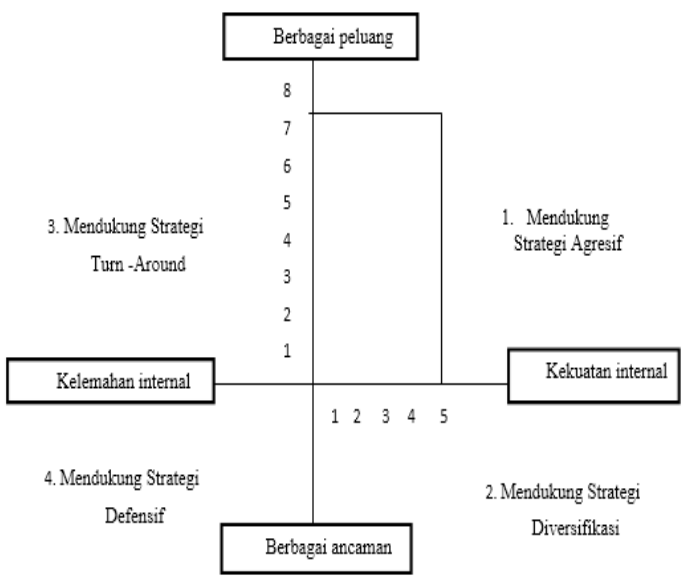

Gambar 3. Matrix Grand Strategy Obyek Wisata Coban Pelangi 


\section{Strategi Pengembangan Obyek Wisata Ledok Ombo}

Obyek wisata alam ledok ombo merupak wisata alam yang berada di Desa Poncokusumo. Keindahan hutan pinus menjadikan ledok ombo semakin diminati wisatawan untuk berwisata dan juga bersantai dari hiruk pikuk keramaian kota. Tidak hanya hutan pinusnya akan tetapi didalamnya juga ada camping ground yang tetap dijaga dan pada zaman penjajahan belanda dahulu ledok ombo memang sudah digunakan sebagai camping ground dan diteruskan dan akan tetap dijaga seperti saat ini.

\section{Tabel 9 Metode Skoring SWOT Obyek Wisata Ledok Ombo}

\begin{tabular}{|c|c|c|c|c|}
\hline No & $\mathrm{S}$ & Stor & Bobot & Total \\
\hline 1. & Hutan pinus yang indah & 5 & $5 / 5=1$ & 5 \\
\hline 2. & $\begin{array}{l}\text { Suasana yang tenzang setta vddra } \\
\text { yang sejuk }\end{array}$ & 5 & $5 / 5=1$ & 5 \\
\hline 3. & $\begin{array}{l}\text { Tempat yang asilu untulk } \\
\text { nongkrong }\end{array}$ & 4 & $45=0.8$ & 3.2 \\
\hline 4. & Outbend & 5 & $5 / 5=1$ & 2 \\
\hline 5. & Camping ground & 5 & $5 / 5=1$ & 5 \\
\hline & Total Keluatan & & & 23.2 \\
\hline No. & $\mathbb{W}$ & Stor & Bobot & Total \\
\hline 1. & Kurangnva kesadaran masyaralatat & 4 & $45=0.8$ & 3.2 \\
\hline 2. & Surangnva minat xisatawan & 4 & $4 / 5=0.8$ & 3.2 \\
\hline 3. & Sampah berserakan & 4 & $45=0.8$ & 3.2 \\
\hline 4. & Banjije di area camping ground & 5 & $5 / 5=1$ & 5 \\
\hline 5. & Jalan yang masih berbatu & 4 & $45=0.8$ & 3.2 \\
\hline & Total Kelemahan & & & 17.5 \\
\hline
\end{tabular}

\begin{tabular}{|c|l|r|r|c|}
\hline No & \multicolumn{1}{|c|}{0} & Skor & \multicolumn{1}{c|}{ Bobot } & Total \\
\hline 1 & Camping ground satu-satunya & 5 & $5 / 5=1$ & 5 \\
\hline 2 & Cafe alam & 5 & $5 / 5=1$ & 5 \\
\hline 3 & Turnamen bmx di bike park & 5 & $5 / 5=1$ & 5 \\
\hline 4. & Outbound edukasi & 5 & $5 / 5=1$ & 5 \\
\hline 5. & Hunting alam & 4 & $4 / 5=0.8$ & 3.2 \\
\hline & Total Peluang & & & 23.2 \\
\hline No. & \multicolumn{1}{|c|}{ T } & Skor & Bobot & Total \\
\hline 1. & Kalah saing dengan wisata baro & 5 & $5 / 5=1$ & 5 \\
\hline 2. & Kurang dukungan masyarakat & 4 & $4 / 5=0.8$ & 3.2 \\
\hline 3. & Kerusakan alam & 4 & $4 / 5=0.8$ & 3.2 \\
\hline 4. & Kurangnva perawatan fasilitas & 3 & $3 / 5=0.6$ & 1.8 \\
\hline 5. & Area outbound rusak & 4 & $4 / 5=0.6$ & 3.2 \\
\hline & Total Ancaman & & & 16.4 \\
\hline
\end{tabular}

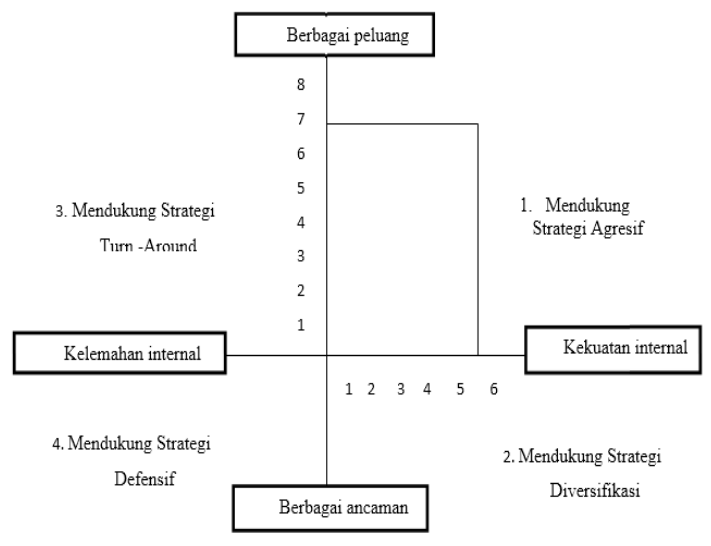

Gambar 4. Matrix Grand Strategy Obyek Wisata Ledok Ombo

\section{Strategi Pengembangan Obyek Wisata Gunungsari Sunset.}

Destinasi wisata di Kabupaten Malang bertambah satu lagi. Perum Perhutani Kesatuan Pemangku Hutan (KPH) Malang baru meresmikan destinasi wisata baru di Desa Gubugklakah, Kecamatan

Poncokusumo yang diberi nama Gunungsari Sunset (GSS).

Tabel 10. Metode Skoring SWOT Obyek Wisata Gunungsari Sunset

\begin{tabular}{|c|l|r|c|c|}
\hline No & \multicolumn{1}{|c|}{ S } & Skor & \multicolumn{1}{c|}{ Bohot } & Total \\
\hline 1 & Panorama yang indah & 5 & $5 / 5=1$ & 5 \\
\hline 2 & Sunset yang indah & 5 & $5 / 5=1$ & 5 \\
\hline 3 & Udara yang sejuk & 4 & $4 / 5=0.8$ & 3.2 \\
\hline 4 & Homestay yang nyaman & 4 & $4 / 5=0.8$ & 3.2 \\
\hline 5 & Spot-spot foto yang bagus & 4 & $4 / 5=0.8$ & 3.2 \\
\hline & Total Keluatan & & & 19.6 \\
\hline No. & \multicolumn{1}{|c|}{ W } & Skor & Bobot & Total \\
\hline 1. & Area yang semakin sempit & 4 & $4 / 5=0.8$ & 3.2 \\
\hline 2. & Pembavaran dua kali & 3 & $3 / 5=0.6$ & 1.8 \\
\hline 3. & Atar yang tidak ramah linglungan & 4 & $4 / 5=0.8$ & 3.2 \\
\hline 4. & Kurangnva penvebaran tempat sampah & 4 & $4 / 5=0.8$ & 3.2 \\
\hline 5. & Kamar kecil yang terbatas & 3 & $3 / 5=0.6$ & 1.8 \\
\hline & Total Kelemahan & & & 13.2 \\
\hline
\end{tabular}




\begin{tabular}{|c|c|c|c|c|}
\hline No & 0 & Skor & Bobot & Total \\
\hline 1 & Homestay elkselutif & 5 & $5 / 5=1$ & 5 \\
\hline 2 & Souvenir gunungsari sunset & 3 & $3 / 5=0.6$ & 1.8 \\
\hline 3 & $\begin{array}{l}\text { Penvelvaan tempat untuk acara ataul } \\
\text { even }\end{array}$ & 5 & $5 / 5=1$ & 5 \\
\hline 4 & Easilitas yang lebih memadai & 4 & $4 / 5=0.8$ & 3.2 \\
\hline \multirow[t]{2}{*}{5.} & Villa gunungsari sunset & 4 & $4 / 5=0.8$ & 3.2 \\
\hline & Total Peluang & & & 18.2 \\
\hline No. & $\mathrm{T}$ & Skor & Bobot & Total \\
\hline 1. & $\begin{array}{l}\text { Menurnnnya minat xisatawxan yang } \\
\text { datang }\end{array}$ & 3 & $3 / 5=0.6$ & 1.8 \\
\hline 2. & $\begin{array}{l}\text { Kalah bersaing dengan wisata yang } \\
\text { lain }\end{array}$ & 3 & $3 / 5=0.6$ & 1.8 \\
\hline 3. & Pembuatan homestay dari kaca & 4 & $4 / 5=0.8$ & 3.2 \\
\hline 4. & Kerusakan Lingkungan & 4 & $4 / 5=0.8$ & 3.2 \\
\hline \multirow[t]{2}{*}{5.} & Terjadinya bencana longsor & 4 & $4 / 5=0.8$ & 3.2 \\
\hline & Total Ancaman & & & 13.2 \\
\hline
\end{tabular}

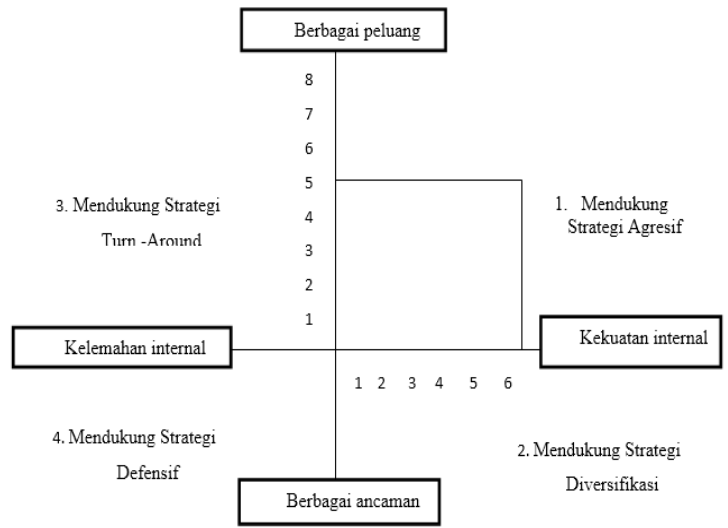

Gambar 5 Matrix Grand Strategy Obyek Wisata Gunungsari Sunset

5. Strategi Pengembangan Obyek Wisata River Tubing Ledok Amprong.

Ledok Amprong adalah nama tempat di hulu sungai Amprong. Sungai Amprong ini juga adalah bagian hulu dari wilayah DAS Brantas. Derasnya aliran hulu sungai Amprong berkisar 10 sampai $30 \mathrm{~km}$ per jam, sehingga menjadi daya tarik wisata, sekaligus dikategorikan wisata ekstrim.
Tabel 11. Metode Skoring SWOT Obyek Wisata River Tubing Ledok Amprong

\begin{tabular}{|c|l|r|c|c|}
\hline No & \multicolumn{1}{|c|}{ S } & \multicolumn{1}{|c|}{ Skor } & \multicolumn{1}{c|}{ Bobot } & Total \\
\hline 1 & Sungai yang berpotensi untuk tubing & 5 & $5 / 5=1$ & 5 \\
\hline 2 & Hitan pinus yang indah & 5 & $5 / 5=1$ & 5 \\
\hline 3 & Suasana yang tenang ala pedesaan & 5 & $5 / 5=1$ & 5 \\
\hline 4 & Uji adrenalin dengan tubing & 5 & $5 / 5=1$ & 5 \\
\hline 5 & Keindahan alam yang mempesona & 4 & $4 / 5=0.8$ & 3.2 \\
\hline & Total Kekuatan & & & 23.2 \\
\hline No. & \multicolumn{1}{|c|}{ W } & Skor & Bobot & Total \\
\hline 1. & Jalan yang rusak & 4 & $5 / 5=1$ & 5 \\
\hline 2. & Warung-warung yang tidak terurus & 3 & $4 / 5=0.8$ & 3.2 \\
\hline 3. & Jauh dari perkampungan & 4 & $4 / 5=0.8$ & 3.2 \\
\hline 4. & Akses yang jauh dari jalan raya & 4 & $4 / 5=0.8$ & 3.2 \\
\hline 5. & $\begin{array}{l}\text { Kurangnya dukungan masyarakat dan } \\
\text { Desa }\end{array}$ & 3 & $3 / 5=0.6$ & 1.8 \\
\hline & Total Kelemahan & & & 13.2 \\
\hline
\end{tabular}

\begin{tabular}{|c|l|r|c|c|}
\hline No & \multicolumn{1}{|c|}{0} & \multicolumn{1}{c|}{ Skor } & \multicolumn{1}{c|}{ Bobot } & \multicolumn{1}{c|}{ Total } \\
\hline 1 & Outbound bagi anak-anak & 5 & $5 / 5=1$ & 5 \\
\hline 2 & Souvenir ledok amprong & 4 & $4 / 5=0.8$ & 3.2 \\
\hline 3 & Kolam renang anak-anak & 4 & $4 / 5=0.8$ & 3.2 \\
\hline 4 & Tubing bagi anak-anak & 5 & $55=1$ & 5 \\
\hline 5. & Mengiluti sertifikasi safeguard & 5 & $5 / 5=1$ & 5 \\
\hline & Total Peluang & & & 21.4 \\
\hline No. & \multicolumn{1}{|c|}{ T } & Skor & Bobot & Total \\
\hline 1. & $\begin{array}{l}\text { Jalan yang terlaku elkstrem untuk } \\
\text { dilevvati }\end{array}$ & 4 & $4 / 5=0.6$ & 3.2 \\
\hline 2. & Bencana Banjir & 4 & $4 / 5=0.6$ & 3.2 \\
\hline 3. & Pohon yang tumbang & 5 & $55=1$ & 5 \\
\hline 4. & Fasilitas yang kurang terawat & 4 & $4 / 5=0.8$ & 3.2 \\
\hline 5. & Kecelakaan saat tubing & 4 & $4 / 5=0.8$ & 3.2 \\
\hline & Total Ancaman & & & 13.2 \\
\hline
\end{tabular}

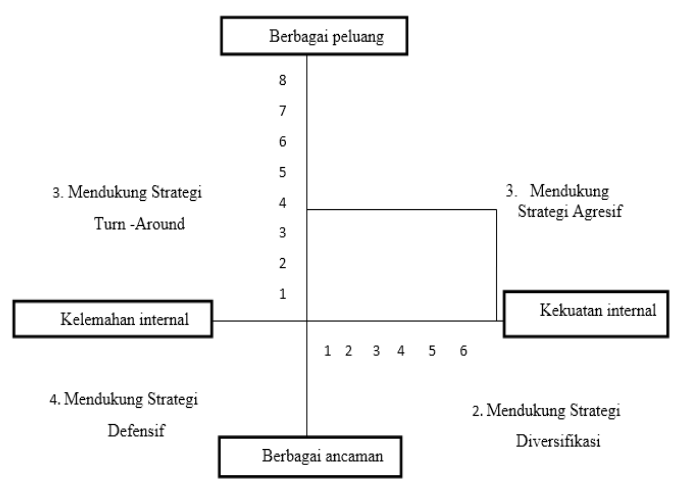

Gambar 6. Matrix Grand Strategy Obyek Wisata River Tubing Ledok Amprong 


\section{Strategi Pengembangan Obyek Wisata River Tubing Sedaer.}

River tubing "Sedaer" berada Desa Drigu Desa Poncokusumo, obyek wisata ini terbilang baru di Kecamatan Poncokusumo. Obyek wisata ni benarbenar menawarkan sensasi yang berbeda karena memiliki pemandangan yang benar-benar pedesaan serta banyaknya tanaman selada air dan juga hutan apel yang masih alami.

Tabel 12 Metode Skoring SWOT Obyek Wisata River Tubing Sedaer

\begin{tabular}{|c|l|r|c|c|}
\hline No & \multicolumn{1}{|c|}{ S } & Skor & \multicolumn{1}{|c|}{ Bobot } & Total \\
\hline 1 & Tanaman apel yang luas & 4 & $4 / 5=0.8$ & 3.2 \\
\hline 2 & Hamparan sawah dan suasan pedesaan & 5 & $5 / 5=1$ & 5 \\
\hline 3 & Udara yang sejuk & 5 & $5 / 5=1$ & 5 \\
\hline 4 & $\begin{array}{l}\text { Sungai yang indah serta batu warna } \\
\text { warni }\end{array}$ & 5 & $5 / 5=1$ & 5 \\
\hline 5 & Paket wisata yang lengkap & 5 & $5 / 5=1$ & 5 \\
\hline & Total Kekuatan & & & 23.2 \\
\hline No. & \multicolumn{1}{|c|}{ W } & Skor & Bobot & Total \\
\hline 1. & Belum ada asuransi & 5 & $5 / 5=1$ & 5 \\
\hline 2. & Jalan yang sepi & 4 & $4 / 5=0.8$ & 3.2 \\
\hline 3. & Keamanan yang kurang terjamin & 4 & $4 / 5=0.8$ & 3.2 \\
\hline 4. & Guide yang belum sertifikasi & 5 & $5 / 5=1$ & 5 \\
\hline 5. & $\begin{array}{l}\text { Fasilitas penunjuang yang belum } \\
\text { lengkap }\end{array}$ & 3 & $3 / 5=0.6$ & 1.8 \\
\hline & Total Kelemahan & & & 18.2 \\
\hline
\end{tabular}

\begin{tabular}{|c|l|r|c|c|}
\hline No & \multicolumn{1}{|c|}{0} & \multicolumn{1}{|c|}{ Skor } & \multicolumn{1}{c|}{ Bobot } & \multicolumn{1}{c|}{ Total } \\
\hline 1 & Mempunyai Tim kesehatan sendiri & 5 & $5 / 5=1$ & 5 \\
\hline 2 & Mempunyai basecamp milik sendiri & 4 & $4 / 5=0.8$ & 3.2 \\
\hline 3 & Peran dukungan pemerintah & 4 & $4 / 5=0.8$ & 3.2 \\
\hline 4 & Pos kemanan dan asuransi & 5 & $5 / 5=1$ & 5 \\
\hline 5. & Promosi wisata yg lebih gencar & 4 & $4 / 5=0.8$ & 3.2 \\
\hline & Total Peluang & & & 19.6 \\
\hline No. & \multicolumn{1}{|c|}{ T } & Skor & Bobot & Total \\
\hline 1. & Kurangnya respon wisatawan & 3 & $3 / 5=0.6$ & 1.8 \\
\hline 2. & $\begin{array}{l}\text { Kalah bersaing dengan wisata air yang } \\
\text { lain }\end{array}$ & 3 & $3 / 5=0.6$ & 1.8 \\
\hline 3. & Peralatan tubing yang kurang aman & 4 & $4 / 5=0.8$ & 3.2 \\
\hline 4. & Terjadi bencana banjir & 4 & $4 / 5=0.8$ & 3.2 \\
\hline 5. & Kecelakaan saat tubing & 4 & $4 / 5=0.8$ & 3.2 \\
\hline & Total Ancaman & & & 13.2 \\
\hline
\end{tabular}

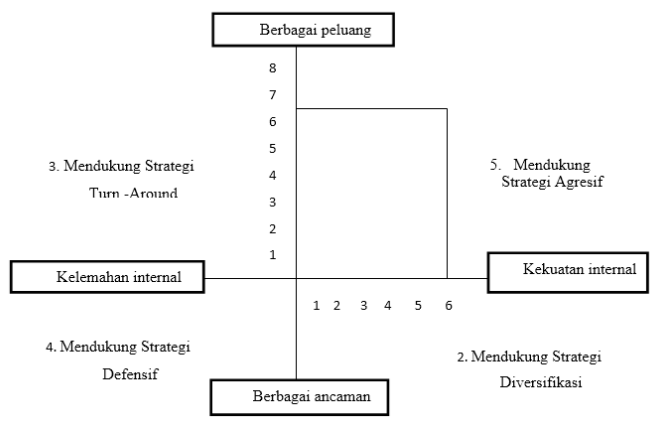

Gambar 7 Matrix Grand Strategy Obyek Wisata River Tubing Sedaer
Tabel 14. Pengembangan Pariwisata Menggunakan WEB

\begin{tabular}{|c|c|c|}
\hline No. & Gambar & Keterangan \\
\hline 1. & 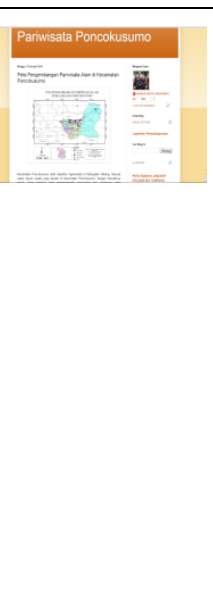 & $\begin{array}{l}\text { Tampilan blogspot } \\
\text { pengembangan } \\
\text { pariwisata di Kecamatan } \\
\text { Poncokusumo. Halaman } \\
\text { web } \\
\text { http://pengembanganpari } \\
\text { wisa } \\
\text { taponcokusumo.blogspo } \\
\text { t.co.id/. dalam blpgspot } \\
\text { tersebut terdapat peta } \\
\text { pengembangan } \\
\text { pariwisata alam yang } \\
\text { berada di Kecamatan } \\
\text { Poncokusumo serta } \\
\text { keterangannya. }\end{array}$ \\
\hline 2. & III & $\begin{array}{l}\text { Sesudah mengupload } \\
\text { foto di google map } \\
\text { wisatawan dapat melihat } \\
\text { apa saja yang ada di } \\
\text { coban bidadari dan dari } \\
\text { reverensi gambar } \\
\text { tersebut bisa menjadikan } \\
\text { coban bidadari sebagai } \\
\text { destinasi wisata rujukan } \\
\text { untuk berwisata bersama } \\
\text { sahabat dan keluarga. }\end{array}$ \\
\hline 3. & 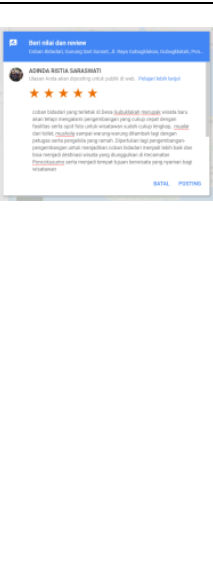 & $\begin{array}{l}\text { Setelah memasukkan } \\
\text { gambar selanjutnya } \\
\text { merupakan memberikan } \\
\text { review berupa } \\
\text { keterangan mengenai } \\
\text { obyek wisata coban } \\
\text { bidadari. Agar } \\
\text { wisatawan dapat } \\
\text { mengetahui terdapat apa } \\
\text { saja di coban bidadari } \\
\text { dan wisatawan dapat } \\
\text { membaca melalui kolom } \\
\text { yang terdapat di google } \\
\text { map. }\end{array}$ \\
\hline
\end{tabular}




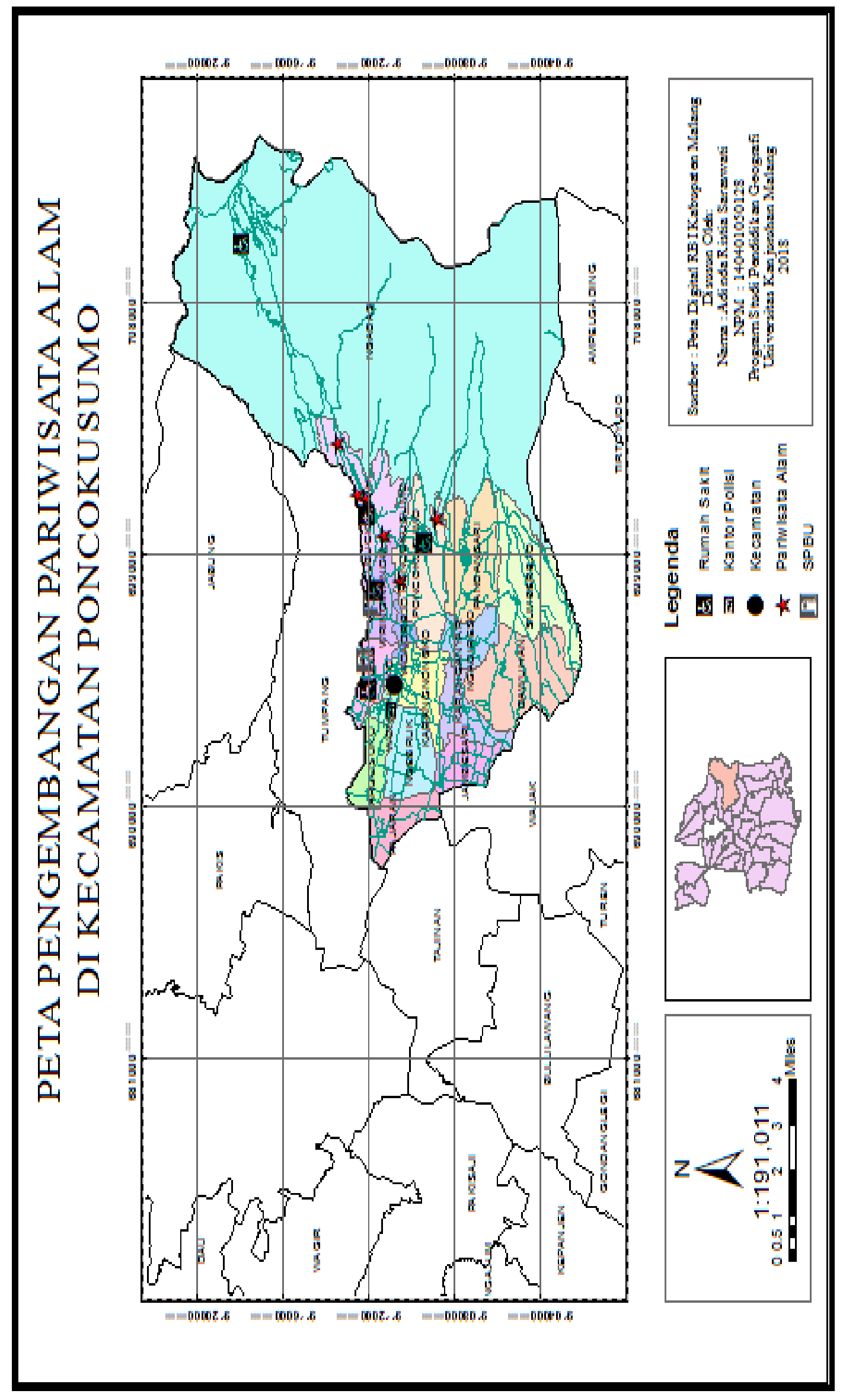




\section{KESIMPULAN}

Berdasarkan tujuan penelitian pengembangan pariwisata di Kecamatan Poncokusumo mempunyai kekuatan dan kelemahan serta peluang dan ancaman dan wisatawan dapat mengetahui wisata apa yang direkomenasi untuk mengisi liburan dan juga menghabiskan waktu dengn keluarga. Pemerintah Kabupaten Malang telah meluncurkan program pariwisata yaitu PONCO WISMO JATU, karena pariwisata merupakan penyumbang devisa Negara ke 2 setelah gas bumi menjadikan pemerintah Kabupaten Malang memajukan dan melakukan perkembangan di bidang pariwisata.

\section{DAFTAR RUJUKAN}

ESRI dalam Eddy Prahasta, 2005, Sistem Informasi Geografis, Bandung: Penerbit Informatika.

Juhadi dan Dewi Liesnoor Setiyowati. 2001. Desain dan Komposisi Peta Tematik. Semarang: Pusat Pengkajian dan Pelayanan Sistem Informasi geografis, Geografi UNNES.

Mustika, AJ, Ika, M. 2016. Geografi Pariwisata. Malang: Ediide Infografika.

Pendit. 2002. Ilmu Pariwisata (Sebuah Pengantar Perdana). Jakarta: Pradnya Paramita

Prahasta, Eddy, 2005, Sistem Informasi Geografis : Tutorial Arcview, Informatika, Bandung.

Turban, Efrain, 2009, Decision Support System and Intelligent Sysrem, Penerbit Andi, Yogyakarta Marpaung, Happy. 2002.
Pengantar Pariwisata. Bandung: Alfabeta. 